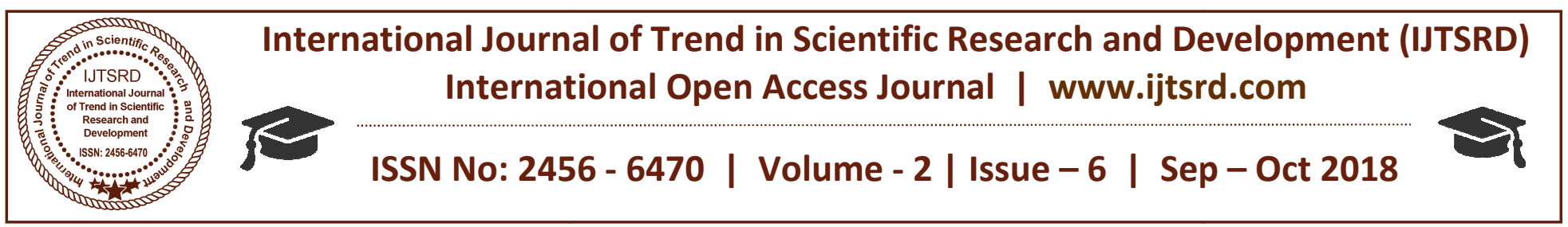

\title{
Problems of Glacier Retreats in the Himalaya and Dimension of Environmental Hazards
}

\author{
Bishnupada Sheet \\ Headmaster, Bhetkipur High School, West Bengal, India
}

\section{Mountain Environments and the Glaciers}

With majestic aesthetic beauty and enormous research notential glaciers and snow fields in the Himaiaya always draw attention of the mountain-lovers and environmental researchers. Mountaineers and trekkers, however, have difficulties in distinguishing snow-patches from glaciers. They often traverse numerous semi-permanent snow patches of avalanche-type while negotiating high ridges and summitl and by mistake identify them as glaciers. By doing so the ignore the fact that these two typical alpine hydrological features do not resemble each other in any manner except their snowy appearance.

By definition glacier ice is a huge mass of slowly moving ice which originates in the arctic and alpine environments above the perpetual snow line, and does not melt completely at any time of the year. Oligin of the glaciers owes to huge amounts of snowfall and their subsequent accumulation under freezing temperature. The first technical definition of glacier was given by the European scientist J. D. Forbes(1843)as" a glacier is not but is a granular compound of ice and water, possessing under certain circumstances, especially when sarurated with moisture, a rude flexibility sensible even to the hand".

An ice age is virtually a prolonged period of tens of millions of years during which extensive ice-sheets occur somewhere upon the earth. At present we are living in a nice age which is known as Quaternary. The Quarernarv geologists believe that there have been at least seven ice ages before the present one; four having occurred in the Pre-Cambrian era of more than 600 million years ago.

Glaciers and Ice Fields in the Himalaya

The Himalaya covers about5, 00,000krn area in the northern part of the Indian subcontinent, out of which3/5'fails. Within the Indian Territory and the rest in Nepal and Bhutan. The word 'Himalaya 'means' the abodeofsnowти.: ice'. Most of the mountain glaciers in the world are nourished in the Himallaya, where about $50,000 \mathrm{~km}\left(1 \mathrm{O}^{\prime} \mathrm{Yo}\right)$ area is covered with as many as 12,000 large and small glaciers and ice caps.(Chattopadhyay,1994,2000. Chattopadhyay and Chatterjee, 2007).

Although most of the glaciers occur in the Great Himalaya (Himadri), the lesser Himalaya also supports a few small glaciers. The glaciers are greater number and length in the Western and Central Himalaya than in its eastern part, This feature can well be compared with the fact that the average altitude of sow-line in the west corresponds approximately with the $5,000 \mathrm{~m}(16,400 \mathrm{ft})$, and in the $5,800 \mathrm{~m}(19,000)$. The lowest elevation down to which the glaciers in the Himalaya descend in the present day are as follows: Eastern Himalaya 4,000m, Central Himalaya(Nepal Himalaya) $3,650 \mathrm{~m}$ and Western Himalaya.2,150m

Impact of Global Warming on Glaiers and Snowfields in the Himalaya

Mountain regions are more sensitive to climate change than any other topographic regions. A study by the United Nations Environment Programme (UNEP) and the International Centre for Integrated Mountain Development (ICIMOD) reveals that the temperature in the Himalayan region has risen by about $1^{\circ} \mathrm{C}$ since1970s (IPCC Report, 200la, 200lb), This pattern of climatic ameliorntion causes meltdown of snow fields and retreat of glaciers at the fastest rate $\left(15 \mathrm{~m} /\right.$ year. $\left.^{1}\right)$ in the world (Mehovic, J. and Blum, J., 2004). 
Reduction and Retreat of glaciers: Glaciers and snowfields are the most valuable treasures of the Himalaya for their both aesthetic and resource values that contribute immensely to its total environmental system. This mountain complex has as many as 1,500glaciers and along with their adjacent snow fields they occupy about $33,000 \mathrm{krn}^{2}$ areas. Recent studies have revealed that almost $67 \%$ of the Himalayan glaciers have reitreated markedly in the past, decades (Ageta and Kadota, 1992; Yamda et al., 1996, Fushimi 2000). The firn-line altitude of glaciers the altitude at which both accumulation and ablation of snow and ice on the glacier remain at equilibrium) is steadily receding upward. And it is estimated that the firn-line attitude of the glaciers in the Western Himalaya is resting at 50-80m higher than the altitude during the first half of the 19thcentury (Pender, 1995).There records show that the Gangotri Glacierin Garwal Himalaya is now retreating by about $30 \mathrm{~m}$ year"،, confirming the view that the rate of ice melting (ablation) from this glacier body is now foster than accumulation <.Sharma, B. Rand Mc Cornick. PG2006),

The following table demonstrates the pattern and rate of retreat of some important glaciers in the Hi malaya:

Table l: Pattern and rate of retreat of some important glaciers in the Western Himalaya

\begin{tabular}{|c|c|c|c|}
\hline \multirow{2}{*}{ Name of glacier } & Pattern of Retreat & \multirow{2}{*}{$\begin{array}{l}\text { Total } \\
\text { Retreat }\end{array}$} & \multirow{2}{*}{$\begin{array}{l}\% \text { of } \\
\text { Retreat }\end{array}$} \\
\hline & Year Rate & & \\
\hline Gangtri Glacier & $\begin{array}{ll}1842-1935 & 7 \mathrm{~m} / \mathrm{yr} \\
1935-1990 & 18 \mathrm{~m} / \mathrm{yr} \\
1990 \text { onwards } & 30 \mathrm{~m} / \mathrm{yr}\end{array}$ & $\begin{array}{c}0.64 \mathrm{~km} \\
1.00 \mathrm{~km} \\
0.5 \mathrm{~km}\end{array}$ & $12 \%$ \\
\hline $\begin{array}{c}\text { Khumbu Glacier } \\
\text { (Mt. Everest expendition route in 1953) }\end{array}$ & 1953 onwards $100 \mathrm{~m} / \mathrm{yr}$ & $5.00 \mathrm{~km}$ & $20 \%$ \\
\hline Glacier of Baspa basin, H.P. & $1962-2001$ & ---- & $19 \%$ \\
\hline Chota Shigri Glacier, H.P. & 1990-2005 IIIÁ---- & --- & $12 \%$ \\
\hline Meola Glacier, Uttaranchal & $1955-2005=34.5 \mathrm{~m} / \mathrm{yr}$ & - & $5 \%$ \\
\hline
\end{tabular}

Source: Alarming Facts of Warming Glaciers-Hasnain- S.I. (2005)

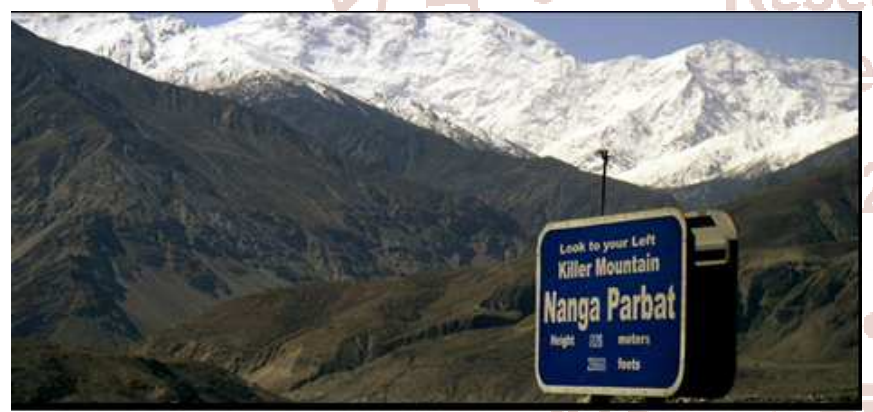

A retreating glacier in Nanga Parbat

Problems of dam burst and flash floods: There is every possibility that the rapidly melting glaciers world swell local lakes in the mountain, trigger in gflash flooding in the narrow valleys downstream. In 1994 a glacier lake outburst in the Lunana region of Bhutan and flooded number of villages below, endangering the lives of thousands of people. The burst of the Dudh Koshi Lake in Nepal in 1997 made similar hazards (Mehovic and $\mathrm{T}<\mathrm{l} " \mathrm{~nm}$. 2005). The experts maintain that that this trend will accelerate in the ensuing years. Creating social and economic problems not only for the villages in the Himalayan foothills but also for the entire South Asian (Report of the International Water Management Institute, 2004)

Variation in the river discharge pattern: As reported in TPCC(1998)glacier melt is expected to increase even further under changed climatic conditions. This would lead to increased flows in some rivers for the first to decades in this century followed by a reduction in flow as the glaciers disappear. As far as the seasonal discha characterise concerned it is presumed that the river flows will increase from January through March $\mathrm{f}$ decrese from April through September. The contribution of snow to the run off of major river in the eastern Himalaya about $10 \%$ (Sharma,1993) but more than $60 \%$ in the western Himalayas (Vohra, 1981). Because the melting season of snow coincides - with the summer monsoon season, any intensification of the monsoon is likely contribute to flood disasters in Himalayan catchments. Such impacts will be observed more in the western Himalay as compared to the eastern Himalaya as because of the higher contribution of snowmelt runoff in the west (Sharma, 1997). 
At present the rivers rising from the Western Himalaya have shown $3-4 \%$ surplus water due to a $10 \%$ increase the melting of the glaciers, and a $30 \%$ increase for those rising from the Eastern Himalayan glaciers. But, after 40 years, when most of these glaciers will cease to diminish South Asia will have water problems. In March 2002 UK's Department of International Development fonded a project called Sagarmatha (Snow and Glacier Aspects of Water Resources Management in the Himalayas) to assess the impact of deglaciation on the seasonal and longterm water resources in snow-fed Himalayan rivers. Parts of the finding of their studies reveal some major facts abot the melting mountain and warming glaciers. As per the report in Upper Indus, there will be initial increases of $14 \%$ and $90 \%$ in mean flows over the next few decades which will be followed by decreasing flows by $30 \%$ and $90 \%$ baseline in the subsequent decades in a 100-years stretch of time. For Bhagirathi (the source stream of Ganga). Uttarkashi, the fows peak will rise of the order of $20 \%$ to $33 \%$ above baseline with in the first few decades and them recede to $50 \%$ of baseline after 50 years.

For Brahmaputrn River, near its source there is a general decrease in decadal mean flows as glaciers are few in the area and flows recede as the permanent snow cover reduces with increasing temperature. The catchments in the eastern Himalaya, which benefit from heavier precipitation of the summer monsoon, are more vulnerable to impacts of degiaciation than those in the west where the monsoon is much weaker.

\section{References for further readings}

1. Chattopadhyay, G. P. (1994): Morphology and Development of Glacier-ice and the Himalaya. Science Courier Vol5(6), 10-14

2. Chattopadhyay, G. P. (2000): Processes and landforms in High altitude and high latitude areas. In Contemporary Dimenstons Geography, edited by N. Prasad \& R Basu, (Univ. of Burdwan).
3. Chattopadhyay, G. P. and Chattejee, A.(2007) global climate change and its impacts on Physical environments and food security in south Asia. Paper presented in the international Seminar on Poverty \& development in south asia to be held, the Department of Geography, University of Calcutta, Kolkata. during 11-13 January 2007.

4. Chattopadhyay, G. P. (2008): Recent retreats of glaciers on the south east-facings slope Kanchenjunga summit complex In the Sikkim Himalaya. Himalayan Geology, 29(2):171-76.

5. IPCC Report (2001): Working Group II lmpacts, Adaptation and Vulnerability, IPCC, Cl-1-11, ASIA.

6. Houghton, J. T., Jenkins, G. J. end Ephraums, J. J. (1990): Climate Change: The IPCC Scientific Assessment. Carnbridg University Press, Cambridge.

7. Report of the International Water Management Institute (2004): Report-Assessment and mitigation of droughts in South-west Asia: Issues and Prospects. Background Document for the Regional workshop on Drought,-assessment and Mitigation Colombo; Sri Lanka.

8. IPCC Report (200la): Climate Change 2001; Report of the working Group 1

9. JPCC Report (2001b): Climate Change 200'1: Report of the Working Group- II Impacts, Adaptation and Vulnerability. IPCC , Chapter-1

10. Mehovic, J. and Blum, J., (2005): Global Warming and Melting Glaciers in Souih Asia: Environment, Economic and Political Implications. SARJD Journal, Vol-1 issue-2.

11. Shanna, B. Rand Mc Cornick, P. G. (2006) "Working Together to Respond to Climate Change" in Annex I Expert Group Seminar in Conjunction with the OECD Global Forum on Sustainable Development, India, on 28, March, 2006(International Water Management Institute 